\section{Infotenimento nos impressos centenários brasileiros}

Fabia Angélica Dejavite

\section{Resumo}

Com base no paradigma da sociedade da informação, este estudo busca determinar de que maneira o jornalismo brasileiro - praticado pelo jornal diário impresso de referência (representado pelos veículos O Estado de S.Paulo e A Tribuna, de Santos) - tem incorporado, abordado e apresentado o conteúdo editorial de infotenimento. Embora seja novo, esse tipo de conteúdo editorial ratifica um exercício corrente da práxis jornalística.

Palauras-chave:

Sociedade da informação, Jornalismo impresso, Jornais centenários brasileiros, Jornalismo de infotenimento

\section{The infotainment in centenary Brazilian newspapers}

\section{Abstract}

Taking into account the information society paradigm , the present study seeks to analyze how Brazilian journalism has incorporated, approached and introduced infotainment editorial content to the reader. The reference for this research were the daily Brazilian newspapers $O$ Estado de S. Paulo and A Tribuna, from Santos. The main conclusion is that the reference newspaper is practicing a new type of journalism called infotainment. Thhough quite new, this editorial content type is a tendence and it can ratify the journalistic current exercise and praxis.

Key words:

Information society, Printed press, Brazilian centennial newspapers, Infotainment journalism 
O desenvolvimento e a expansão das tecnologias de informação têm provocado novas reestruturações e mudanças de certos aspectos da produção, distribuição e recepção da mídia tradicional. Se antes os antigos sistemas tendiam a ser uma forma de comunicar de mão única, os meios, no entanto, permitem uma pluralidade e uma interatividade muito maiores.

A combinação de tecnologias como os satélites, a televisão, o computador, o telefone e o cabo de fibra ótica colocaram o mundo em um sistema unificado de informação e de diversão. Com a mídia gerando formas mais amplas de escolhas para o consumidor, há o surgimento de públicos específicos e uma demanda cultural maior. Nesse sentido, o entretenimento, junto à informação, aparece como um dos valores emergentes do cenário contemporâneo.

No entanto na área comunicacional, o entretenimento ainda não se estabeleceu em objeto de pesquisa. Isso ocorre, provavelmente, porque grande parte das pesquisas nesse campo científico não o tem como foco de investigação, preferindo focalizar a mídia em geral. No jornalismo, esse assunto é tido como um subproduto ou, até mesmo, um desvio da atenção do público de assuntos de maior importância, como a política e a economia. Os receptores que consomem esse tipo de informação são considerados, muitas vezes, pessoas sem faculdade de julgamento e fáceis de serem manipuladas.

Entretanto, por mais que o entretenimento horrorize os críticos considerados politicamente corretos, as notícias que entretêm ganham cada vez mais espaços nos veículos jornalísticos. No Brasil, jornais impressos tradicionais, como por exemplo, a Folha de S.Paulo, A Tribuna, de Santos, e O Estado de S. Paulo, Zero Hora, O Globo, entre outros, têm passado a
Por mais que o entretenimento

horrorize os críticos considerados politicamente corretos, as notícias que entretêm ganham cada vez mais espaços nos veículos jornalísticos oferecer páginas mais leves e agradáveis, além de fornecerem informações distintas de tempos atrás. Esse conteúdo tem sido denominado jornalismo de INFOtenimento (uma das mais recentes especialidades jornalísticas). Agora, a informação e o entretenimento - até então vistos como antagônicos - são oferecidos ao mesmo tempo em uma notícia.

Assim, sob a luz do paradigma da sociedade da informação, este artigo busca caracterizar esse novo fazer jornalístico. Além disso, tem por objetivo estabelecer, por meio da análise do jornal diário impresso de referência (um dos meios mais tradicionais), como essa especialidade vem sendo apresentada em seu espaço editorial. Desse modo, empreendeu-se um estudo comparativo com os jornais A Tribuna (de Santos) e O Estado de S.Paulo (veículos centenários e referenciais da imprensa paulista e brasileira).

Do ponto de vista metodológico, esta pesquisa possui abordagem indutiva, processo do qual parte-se de dados particulares, suficientemente constatados e inferese uma verdade geral ou universal. Para tanto, emprega-se as técnicas da pesquisa bibliográfica, documental (análise dos dois jornais). É importante salientar que a pesquisa documental deu-se com o sorteio de um mês.

A partir daí, a análise deu-se por meio do censo (teste das hipóteses em todas as edições do mês) nos anos de 1995, 1999 e 2007. Os anos analisados foram selecionados por serem historicamente representativos. Nesse período, o jornalismo impresso brasileiro sofreu muitas modificações com o surgimento da internet, a chegada do novo milênio, a expansão das novas tecnologias e 
o desenvolvimento da sociedade da informação. Para a amostragem do material, realizouse um sorteio que definiu a terceira semana do mês de maio dos respectivos anos.

A leitura dos jornais foi realizada em duas fases, identificando os seguintes dados: (1) o conteúdo da matéria (por exemplo: moda, gastronomia etc.), que se deu por meio da leitura do título; e (2) o assunto enfatizado em cada matéria (por exemplo, homenagem), feito por meio da leitura integral do texto. Para ser codificada em uma das tipologias, cada matéria teve de apresentar uma ênfase ou assunto particular maior do que $50 \%$ ou mais da história. Em seguida, observaram-se as mudanças gráficas implantadas durante o período.

\section{Sociedade da informação e entretenimento}

A sociedade da informação é a fase histórica atual cuja base fundamenta-se principalmente nas novas tecnologias da mídia, no saber científico, na prestação de serviços e no consumo. Nela as esferas da comunicação, do lazer e do consumo são as que sofrem os impactos mais importantes desses fenômenos e suscitam novas formas de interação comportamental. Na opinião de Maffesoli (1989), a humanidade - depois de dois séculos sob domínio de Prometeu (o deus grego do trabalho) - foi libertada por Dionísio (o deus grego do prazer).

Para Castells (1999: 21), o que caracteriza essa nova etapa é a aplicação do saber e da informação à geração de conhecimento e aos dispositivos de processamento/comunicação de informações, em um circuito de feedback cumulativo entre inovação e seus usos. As novas tecnologias da informação não são apenas ferramentas a serem usadas, mas processos a serem desenvolvidos. A comunicação, por sua vez, encontra-se desmassificada. Os meios impulsionam um contínuo fluxo de informação necessário às pessoas e às organizações. Essa característica apresenta-se de maneira diversa do passado recente, em que a mídia tendia a dirigir seu conteúdo a um público mais heterogêneo.

Os lares estão equipados com computadores e toda a parafernália possível de novas tecnologias, constituindo-se em novos espaços que organizam o trabalho e a diversão. E com essa multiplicação de alternativas de divertimentos caseiros proporcionada pelas novas tecnologias e pelas convencionais recicladas, passa a ser mais atraente ficar em casa.

De acordo com Toffler (1980: 382), o lar - as cabanas eletrônicas - com as suas múltiplas opções de entretenimento e atividades domésticas é o centro da sociedade ou, mais precisamente, o ponto focal de todas as mudanças desencadeadas pela sociedade da informação e se torna uma unidade de trabalho e de lazer.

Desse modo, o entretenimento há muito tempo relegado e colocado em segundo plano apresenta-se como um dos valores principais da sociedade da informação. Seu objetivo é proporcionar uma válvula de distração, de prazer e de diversão às pessoas, ora ajudando-as a uma ruptura com a vida real (por meio da evasão para uma realidade diferente da vivenciada rotineiramente), ora promovendo a formação intelectual.

A ele cabe ainda diminuir as tensões que ameaçam os indivíduos a serem levados à doença ou à loucura, à liberação e à renovação de suas energias; além de fornecer segurança emocional ao promover o descanso e ocupar o tempo livre, isto é, aquele tempo fora do trabalho. Neal Gabler (1999: 23) 
considera-o como tudo aquilo que é promovido pela mídia, ou seja, filmes, rock, romances sanguinários, histórias em quadrinhos, televisão, jogos cativos.

Desde as primeiras pesquisas até o momento, os estudos sobre entretenimento dividem-se em duas perspectivas: uma otimista e outra pessimista. A primeira concebe-o como uma possibilidade de contribuição para o crescimento do indivíduo, propiciando alívio das tensões do cotidiano e equilíbrio de sua personalidade, sendo, portanto, algo necessário e útil. A segunda corrente o tem como um instrumento de alienação, em prol de determinadas ideologias, servindo para manipular as pessoas em busca de objetivos políticos e econômicos.

Defleur e Ball-Rockeach (1993: 324) avaliam que o entretenimento é uma importante ferramenta de socialização, pois constitui uma forma de nos tornarmos sociais, aprender papéis, normas e valores, ao lidar com os outros. Certamente, o entretenimento dissemina o triunfo da emoção sobre a razão. Porém não há, mesmo assim, nenhum motivo suficiente que justifique julgá-lo como algo menor, pois na sociedade da informação ele se faz cada vez mais importante, tornando-se quase obrigatório.

Como argumenta Dumazedier (2001), por meio do entretenimento o homem constrói um tempo parecido com a scholé grega proposta por Aristóteles, com o intuito de caminhar, seguramente, em seu processo de autoformação constante, informando-se e, ao mesmo tempo, divertindo-se.

Nesse sentido, o entretenimento apresenta-se atualmente como um fator diferenciado de pauta jornalística, especialmente para o jornal diário impresso, na medida em que esse meio busca interagir
Desde as primeiras pesquisas até o momento, os estudos sobre entretenimento dividem-se em duas perspectivas: uma otimista e outra pessimista e satisfazer as necessida des e interesses do receptor contemporâneo.

\section{Jornalismo de INFOtenimento}

Para o público, o entretenimento é simplesmente aquilo que entretém, aquela matéria que o informa e diverte ao mesmo tempo, sendo o seu inverso aquele conteúdo que não o agrada. Um grande engano é pensar que para atingir os leitores da classe A e B (considerados os mais intelectuais) é obrigatório publicar apenas informações sobre conteúdos mais sérios: economia e política, por exemplo. Esses leitores estão também expostos ao que for publicado em outras editorias, tais como turismo e suplementos televisivos.

O receptor (com os seus novos princípios de receber a informação) exige que a notícia na atualidade - independentemente do meio em que estiver inserida - informe, distraia e também lhe traga uma formação sobre o assunto publicado. Esse tipo de conteúdo tem sido denominado notícia light. Se as informações jornalísticas não tiverem essas características, não vão chamar a atenção da audiência. Essa, por sua vez, é de fácil entendimento, efêmera, de circulação intensa e busca divertir. Ao que parece, nada mais é do que a solicitação feita pelo receptor da sociedade da informação na espera de encontrar uma matéria que, ao mesmo tempo, satisfaça suas necessidades e seus interesses de formar, informar e distrair, permitindolhe vivenciar o fato, já que o consumo da informação é feito naquele tempo destinado ao lazer, à diversão.

Nesse sentido, o jornalismo de INFOtenimento expressa, hoje, a intenção editorial que busca contentar essa necessidade do receptor. $\mathrm{O}$ neologismo tem origem no inglês infotainment (formado pelas palavras information 
e entertainment) e emergiu durante a década de 1980; porém, somente ganhou notoriedade no final dos anos 1990.

Grosso modo, o jornalismo de INFOtenimento é o espaço destinado às matérias que visam informar e entreter, como, por exemplo, os assuntos sobre estilo de vida, as fofocas e as notícias de interesse humano - os quais atraem, sim, o público. Esse termo sintetiza, de maneira clara e objetiva, a intenção editorial do papel de entreter no jornalismo, pois segue seus princípios básicos ao mesmo tempo em que atende às necessidades de informação do receptor dos dias de hoje. Enfim, manifesta aquele conteúdo que informa com diversão.

Historicamente, existe o registro de que no jornalismo o conteúdo de entretenimento é (ou afinal tem sido) um assunto relegado tanto pela academia como por boa parte dos profissionais, porque, em geral, há diferenciações que sugerem que as notícias são informativas, enquanto o divertimento não o é.

A fronteira entre jornalismo e entretenimento nunca foi nítida e a sobreposição é quase inevitável na contemporaneidade. Nessa área, delimitar e distinguir o que significa entreter e informar não é tarefa fácil (se é que isso seja realmente possível).

Tradicionalmente, sempre coube ao jornalismo o papel de informar e formar a opinião pública sobre o que acontece no mundo real, com base na verdade, nas coisas que acontecem no cotidiano das pessoas. Já o entretenimento destinou-se a explorar a ficção, chamar a atenção e divertir as pessoas. Contudo, a chegada do jornalismo de INFOtenimento tem contestado essa ideologia dominante da prática jornalística e, aos poucos, terá de ser mudada.

No jornalismo de INFOtenimento uma mesma matéria pode muito bem informar, entretendo ou, então, entreter por meio da infor- mação. Nele, o limite ético (debatido até agora) que separa jornalismo e entretenimento não existe. Desse modo, tem-se, como exemplo, as revistas eletrônicas ou mesmo as especializadas em celebridades. Nunca, como agora, houve tanto show da vida como o que o programa Fantástico, da Rede Globo, anuncia desde 1973.

As matérias tidas classificadas como jornalismo de INFOtenimento satisfazem nossas curiosidades, estimulam nossas aspirações, possibilitam extravasar nossas frustrações e nutrem nossa imaginação. Os mais velhos (aqueles com mais de 30 anos, como a autora deste artigo) devem se lembrar da Zebrinha que anunciava os resultados dos jogos da Loteria Esportiva. Ao mesmo tempo em que eram divulgados os resultados da rodada futebolística no país, o público era brindado pelo bom humor do animalzinho (que ria quando um time tradicional perdia para um de menor destaque).

No entanto, o receio maior é o de que a notícia light se sobreponha ao conteúdo mais sério (como o de política e o de economia) e mude o que se conhece por notícia. Essa, na verdade, tem sido uma das discussões mais acaloradas dentro da área jornalística na atualidade. A junção entre entretenimento e informação faz com que o jornalismo de INFOtenimento não seja, por isso, facilmente aceito como algo autêntico.

Já em 1962, o filósofo Jürgen Habermas (1984: 200-01) em sua obra Mudança estrutural da esfera pública, argumentava que os limites entre as notícias e os conteúdos de entretenimento estavam borrados, porque as pessoas preferiam as informações que entretinham e suas imediatas recompensas, em decorrência da atração dos meios audiovisuais, a televisão e o rádio.

\author{
nunca foi nítida e \\ a sobreposição é \\ quase inevitável na \\ contemporaneidade \\ A fronteira \\ entre jornalismo
}


Para Habermas, esse borrar de limites dese nhava, claramente, uma ligação de diferentes níveis de realidade, cuja base do denominador comum, do assim chamado human interest, surge do mixtum compositum, ou seja, de um entretenimento ao mesmo tempo agradável e facilmente digerível, que tende a substituir a captação do real por aquilo que está pronto para o consumo, desviando o receptor a estímulos somente destinados à distração em detrimento do uso da razão.

Ainda segundo ele, "o rádio, o cinema e a televisão levam gradualmente ao desaparecimento da distância que o leitor precisa guardar ante a letra impressa - uma distância que a privacidade da simulação tanto solicitava quanto a esfera pública de uma troca de idéias sobre o que havia sido lido acabava possibilitando" (idem, ibidem).

Contudo, outros autores, como DeFleur e Ball-Rokeach (1993: 303), por exemplo, acreditam que, ao limitar a idéia de informação a noticiário, sugere-se que o aprendizado advindo dos divertimentos não tem relevância, já que não importam quais são os significados que as pessoas constroem deles ou se se baseiam em sua socialização. Para eles, é enganoso afirmar que notícias são informações e o entretenimento, não.

Mas que tipos de informações podem ser consideradas jornalismo de INFOtenimento? O conteúdo dessa especialização é definido de acordo com a narrativa da matéria (quando essa lança mão de recursos como a personalização, a dramatização, o segredo, o contar em capítulos) e também de acordo com os conteúdos (assuntos).

Desse modo, segundo Dejavite (2006), jornalismo de INFOtenimento é a especialidade voltada à informação e ao entretenimento, tais como: comportamento, hobbies, esportes,
O conteúdo sério seria aquela matéria que aprofunda, investiga, critica e transmite informações novas, tendo por finalidade o ponto de reflexão moda, celebridades, gastronomia (bebidas, culinária etc), casa e decoração, datas comemorativas, automóvel e acessórios, comportamento (por exemplo, dia-a-dia, opinião pública), vendas e marketing, propaganda, cinema, televisão, vídeo, internet, rádio, música, teatro, dança, espetáculos, eventos, indústria editorial, beleza e estética (ex.: maquiagem, cabelo, dietas, corpo, pele); "faça você mesmo" (ex.: jardinagem, pintura, consertos em geral, bijuterias, artesanato), turismo e lazer (viagem, passeios, bares e restaurantes, festas, aviação civil), consumo, artes plásticas, design, arquitetura e urbanismo, fotografia, cultura (patrimônio, memória, histórico, folclore, museus) jogos e diversões, fofocas, coluna social, ilustração, infográficos, curiosidades, chisties, charges, previsão do tempo, investimentos pessoais, crendices (religiões, ritos, esoterismo, futurologia, fé), formação pessoal (seminários, cursos, palestras, congressos) e empreendedorismo.

Não são enquadrados neste conceito conteúdos não jornalísticos, como publicidade, horóscopo, palavras cruzadas, quadrinhos, contos, poesias, que, embora tenham intenção de entreter, não podem ser determinados como construções jornalísticas, já que exploram a ficção.

Entretanto, devido ao seu caráter híbrido (informação e entretenimento; narração e formato), muitos dos conteúdos propostos acima esbarram em conceitos pré-estabelecidos tanto no âmbito profissional quanto no acadêmico, pois está na contraposição daquilo que se convencionou como conteúdo sério ou não dentro do jornalismo.

O conteúdo sério seria aquela matéria que aprofunda, investiga, critica e transmite informações novas, tendo por finalidade o ponto de reflexão. O segundo, aquele que somente diverte, tem humor, atrai o receptor por 
trazer assuntos mais amenos, light, o que, para muitos, não traz nada de novo, apenas algo velho, com outra roupagem, que ajuda a promover ideologias, como a do consumo e a do mercado.

No entanto, em pleno século XXI, o conteúdo editorial jornalístico não pode mais ser limitado a esse paradigma, pois ao se hierarquizar e reduzir determinados assuntos como entretenimento e desvanecer suas possibilidades críticas, ao enquadrá-los como não importantes, com certeza, minimizam-se os aspectos políticos, os sociais, os culturais e os psicológicos do divertimento. Na verdade, o que realmente diferencia uma e outra prática (o sério do não-sério) é menos o conteúdo e mais a forma de veicular a informação.

Na prática, muitos conteúdos considerados como sérios também podem ser considerados não-sérios. Por exemplo, quando uma charge de jornal satiriza um assunto que está na manchete da primeira página, dando-lhe uma nova exterioridade por meio de dados acrescidos pelo ponto de vista do chargista ou, então, por um ângulo não explorado. Aparentemente, nesse caso, aquilo que se denominou de conteúdo sério (a política) apresenta-se como uma roupagem não séria.

A fotografia, a própria diagramação, o infográfico, a tabela, a ilustração e o gráfico são outros exemplos, que, muitas vezes, falam mais ao leitor do que o texto, porém de uma maneira light, amena, oferecendo a imagem, os números, as cores, o inusitado, o contraponto; isso porque ao mesmo tempo ilustram e dão credibilidade à informação. Há ainda nos jornais outros espaços que também privilegiam o entretenimento, caso das crônicas, das colunas e dos artigos.

Enfim, o jornalismo de infotenimento integra-se aos padrões jornalísticos. Sua articu- lação e propagação associam-se às suas muitas responsabilidades sociais e culturais. Seu conteúdo editorial alia-se à seriedade, à leveza, à precisão e à ética, tal como outras especialidades jornalísticas, relatando informações nacionais, internacionais, locais e regionais em todos os gêneros jornalísticos, ao mesmo tempo em que informa e distrai o receptor.

\section{Jornais centenários impressos e o jornalismo de INFOtenimento}

Achegada da internet em meados da década de 1990 fez com que o jornal impresso tivesse que realizar mudanças mais rápidas em vista das que ocorreram anteriormente no século $\mathrm{XX}$, com o surgimento do rádio e da televisão.

Depois da Segunda Guerra Mundial, com o aparecimento de seu mais forte concorrente - a tevê -, o jornal realmente passou a se preocupar em oferecer informações mais específicas a seu público e tornar mais atrativo visualmente. Com isso, o jornal diário impresso foi obrigado a adotar características desse seu concorrente, procurando empregar novos recursos editoriais e gráficos na tentativa de seduzir o leitor. Em meados dos anos de 1990, com o surgimento da internet, o jornal sentiuse novamente obrigado a procurar novas formas de veicular a informação e repensar seu papel junto ao público. Ocorreu, mais uma vez, uma nova reestruturação gráfica e editorial.

De acordo com a pesquisa empreendida pela autora deste artigo junto aos veículos $O$ Estado de S.Paulo e A Tribuna, de Santos, nos anos de 1995 a 2007, muitas transformações foram efetuadas pelo meio. Entre elas, destacam-se a valorização do título e do subtítulo, que ganharam letras maiores e maior relevância na página, sendo, agora, tão ou mais importantes do que o texto. No que cabe aos 
títulos, a predominância ainda é para os discursivos. No entanto, o corpo foi aumentado, bem como o destaque do negrito e do espaço em branco.

Já o subtítulo, entre 1995 e 1999, havia sido substituído pelo antetítulo ou chapéu. Em 2007, teve sua função ampliada, possuindo o papel de ser alçado à primeira chamada da matéria. Com isso, a informação ficou mais ágil e fácil de ser entendida. Agora, esse recurso é mais extenso, maior em relação ao texto da chamada. Ele vem logo abaixo do título e é valorizado pelo espaço em branco e também pelo tamanho da letra, (com serifa para facilitar a leitura). No $O$ Estado de $S$. Paulo, os subtítulos vieram, muitas vezes, caracterizados como um texto de webjornalismo, tendo algumas palavras destacadas em negrito, principalmente na primeira página.

Além deles, o boxe, o olho e o intertítulo também ganharam um novo status, tornando-se elementos valiosos para a compreensão da notícia. O uso desses itens deu-se gradativamente. No início eram mais explorados nas editorias de política e cultura, depois passaram a ocupar todas as editorias. $\mathrm{O}$ boxe vem agora destacado por fios e, às vezes, marcado pelo espaço em branco. Isso ocorre em matérias mais longas, em que as informações contidas são mais relevantes e merecem ser valorizadas. Antes, tanto no O Estado de S.Paulo quanto na $A$ Tribuna esse elemento era preterido pela matéria retranca.

Outro recurso que também ganhou destaque foi o olho, possuindo um recurso gráfico para destacá-lo (fio e cor azul, além do espaço em branco). Recebeu até uma pequena retranca, a palavra Frase, denominada dessa maneira em ambos os jornais. Surge sempre que o editor quer destacar algo sobre algum fato da página, em qualquer editoria. Muitas

\section{A infografia passou a ser um dos elementos editoriais mais importantes, destacando-se em relação ao texto}

vezes, desempenha a função de legenda. E o intertítulo, devido à influência da internet, nunca foi tão necessário, pois é fundamental para dar melhor melhor compreensão ao fato. Com isso, a contingüidade do texto foi de certa forma quebrada, pois, agora, ele vem blocado, como o é na internet.

O texto era predominante nos anos de 1995 e 1999 em relação aos outros elementos que compuseram as páginas dos dois jornais centenários. No entanto, observou-se que, nesse intervalo de quatro anos, o mesmo passou a ceder espaço às fotografias e também aos infográficos. Os outros elementos gráficoeditoriais, como o título, o olho, o boxe e os infográficos não eram tão valorizados nesse período. No entanto, em 2007, em ambos os veículos registrou-se também que tanto o texto das matérias quanto o das chamadas ficaram mais curto e passaram a ser não mais o elemento relevante.

A infografia passou a ser, agora, um dos elementos editoriais mais importantes, destacando-se em relação ao texto. Esse recurso é utilizado quando se precisa da linguagem visual como apoio à escrita. Tem a função no jornal diário de tornar a informação mais rápida de ser assimilada e aponta-se como a contribuição mais preciosa da internet, segundo as entrevistas empreendidas, já que surge com o desenvolvimento da tecnologia. No webjornalismo, é tido como uma das opções básicas de formato da notícia, pois agrega informação e imagem.

A fotografia expressou-se como a vedete dos projetos gráfico-editoriais dos dois veículos, sendo a que recebeu o melhor tratamento e destaque. Hoje, possui autonomia em relação ao texto. Aparece em todas as folhas, porém são editadas, em média, três em cada uma, para que ela tenha o espaço merecido e para que o 
leitor não seja bombardeado por várias informações imagéticas. Todas são coloridas. Em relação ao seu tratamento e exposição, a principal mudança ocorreu na primeira página, onde as imagens foram mais valorizadas, inclusive em extensão.

Como conteúdos, foram introduzidos diferentes assuntos dentro das editorias existentes, além de terem sido instituídos outros para criar uma nova interação com o leitor, como a foto-leitor. Assuntos que não tinham importância nos anos de 1995 e 1999 passaram a sobressair em 2007, como exemplo, matérias sobre saúde (qualidade de vida), moda, gastronomia. Essa última ganhou até um caderno, no O Estado de S. Paulo, intitulado Paladar.

Outros conteúdos tradicionais ganharam novas abordagens, como economia, que agregou a perspectiva dos negócios; esportes, que passou a ser um caderno. E mesmo a editoria de cultura, que tem agora mais ênfase nos serviços. No O Estado de S. Paulo foi criado o Guia (que oferece serviços, lazer e entretenimento). Com essas reformulações, os jornais ampliaram a quantidade de conteúdos para o leitor com a concepção de suplementos e a "cadernização" de assuntos do dia-a-dia.

Em termos de diagramação, em 2007, a mais importante modificação foi a inserção de cores para o auxílio na "navegação" pelos cadernos. Desse modo, todo o jornal foi mapeado para que cada editoria tivesse uma cor característica. Os tons mais clássicos e elegantes como o verde, o azul e o marrom remeteram aos conteúdos tradicionais, como política, economia e internacional. Já os cadernos ligados mais diretamente ao INFOtenimento (cultura e esportes) tiveram as gradações de amarelo e alaranjado.

Enfim, cada editoriaganhou uma escalacromática própria e toda peça gráfica e elemento de acordo com sua localização. A cor usada como ferramenta de atenção (em chapéus de título, de página ou de algum elemento principal dentro da infografia) é o vermelho, que aparece assim em todas as páginas dos cadernos. Nos anos de 1995 e 1999, as cores não eram exploradas pelos seus diversos matizes. Isso porque a possibilidade de inserção de cor de acordo com a tecnologia da época e a demanda por parte do leitor ainda estavam começando. Nesse período, predominava tanto nas fotos quanto nos recursos gráficos, o vermelho e o amarelo, cores tradicionais e as mais exploradas pela imprensa. Observase que, em ambos os anos, os jornais davam mais atenção ao corpo de texto do que ao título, ao olho e às imagens (que freqüentemente eram pequenas).

No entanto, é visível o aumento do espaço em branco. A primeira página foi a que mais explorou esse recurso, principalmente entre as linhas dos títulos e subtítulos e na separação do corpo da chamada e o título referente a ele. $\mathrm{O}$ espaço em branco manifestou-se ainda para valorizar as fotos. Essa nova característica gráfica fez com que o fio - o mais usado em 1995 - fosse preterido. O uso desse recurso deu-se também nas páginas internas. Sua diminuição, ao que tudo indica, levou a valorização do olho. As letras ficaram comprimidas entre uma linha e outra. Esse recurso aparece, hoje, com uma área de respiro e facilita a leitura, tornando a visualização dos elementos icônicos na página mais agradáveis e a informação mais compreendida. A leitura ficou mais prazerosa. O espaço em branco passou, desse modo, a ditar a estética da página, deixando-a mais fácil de ser lida e com melhor visualização de todos os assuntos e dos vários elementos icônicos e textuais. 
Em relação às fotografias, em 2007, usa-se apenas uma ou - no máximo - duas por página. Nas edições atuais, raramente o corpo de texto de uma matéria recebe mais espaço do que as imagens, infográficos ou ilustrações.

O fio, muito usado nos projetos anteriores, de 1995 e 1999, é usado com comedimento na diagramação atual. Aparece nos cabeçalhos, no olho, no boxe e na assinatura das matérias. Acompanha a cor da editoria no cabeçalho.

\section{Considerações finais}

Apesar de o entretenimento ser um dos valores principais das sociedades ocidentais e um dos mais importantes conteúdos da mídia, ainda não se constituiu em foco de pesquisa dentro das Ciências da Comunicação - principalmente quando ele está associado aos trabalhos no campo jornalístico. No entanto, a função de entreter no jornalismo interage perfeitamente com aquela tradicionalmente reconhecida como de vigilância da sociedade. Isso porque a boa informação jornalística não é algo necessariamente sem humor, pesada e séria. Desse modo, o aparecimento desse tipo de conteúdo nas páginas do jornal diário impresso apresenta-se como uma resposta positiva às mudanças dos processos cognitivos da nova geração de receptores, cidadãos/leitores/ consumidores da sociedade da informação.

Hoje, a comunicação se faz cada vez mais segmentada, assim, é preciso inovar e experimentar novas formas de fazer a audiência assimilar o jornalismo (em especial as informações advindas do jornal impresso). Isso, no entanto, não significa descaracterizá-lo, mas sim, elevá-lo à sintonia com o leitor, que é, de fato, a sua missão principal.

Os dois jornais mantiveram o tradicionalismo conhecido, que o tornaram líderes no mercado de jornais brasileiros. No entanto,
Com a comunicação cada vez mais segmentada, é preciso inovar e experimentar novas formas de fazer a audiência assimilar o jornalismo modernizaram-se tanto no conteúdo quanto no projeto gráfico. Em 2007, apresentam-se totalmente reformulados e bem diferentes dos anos anteriores. O processo se deu de forma gradativa para acostumar o público aos poucos com as diversas mudanças.

Dessa forma, em 2007, tanto O Estado de S. Paulo quanto a $A$ Tribuna passaram a adotar definitivamente novos padrões gráficos e estéticos para tornar a leitura mais agradável e fazer frente ao novo formato da notícia imposto pela internet. Além de inserir conteúdos de INFOtenimento para atrair e satisfazer a necessidade do novo cidadão-leitor-consumidor da sociedade da informação.

Nesse sentido, observa-se a introdução de novos assuntos, que visaram ao reposicionamento do conteúdo editorial nos dois jornais. O que se verificou é que esse meio está procurando atender a demanda de informações dos novos leitores sem, contudo, deixar de oferecer os assuntos antigos.

Eles o fazem oferecendo as notícias de INFOtenimento com a intenção de satisfazer os interesses e necessidades de se informar e entreter do atual receptor da mídia impressa. $\mathrm{O}$ aparecimento desses conteúdos deve-se, ainda, à necessidade de interagir com as camadas de leitores a serem melhores atingidas - mulheres e jovens - e também com aqueles potenciais que não têm o hábito de ler um veículo impresso.

Também revela a preocupação por parte das empresas jornalísticas de estarem em sintonia com esse novo receptor. Essas transformações editoriais e gráficas apresentam-se como uma opção editorial inovadora, sendo um exercício autêntico do jornalismo de qualidade. Coloca-se, ainda, como uma das muitas possibilidades para a elaboração de uma linha editorial também inovadora e contemporânea. 
Entretanto, nunca será igual em todos os veículos. Cada um, de acordo com suas características e seu público, deve definir a dosagem certa de conteúdos e recursos gráficos oferecidos ao seu leitor, sempre tendo a ética como fiel da balança. $\mathrm{O}$ fato de o jornal impresso diário realizar tais mudanças evidencia a necessidade de fazer com que o jornalismo praticado por esse meio continue a cumprir seu papel de integrador social da melhor maneira possível.

Desse modo, pesquisar e debater o entretenimento no jornalismo implica questionar constantemente certas verdades dominantes em relação à práxis jornalística, entendidas muitas vezes como prejudiciais iniciativas que aproximam jornalismo, público e mercado. Decifrar como funciona o jornalismo de INFOtenimento em outros meios, a relevância e o papel do entretenimento no jornalismo são questões em aberto e devem ser respondidas o quanto antes, pois essa especialidade será cada vez mais essencial.

\section{Sobre a autora}

Fabia Angélica Dejavite, Doutora pela Universidade Anhembi-Morumbi de São Paulo. email:fdejavite@hotmail.com

\section{Referências}

BALDASTY, G. J. The commercialization of news in the nineteenth century. Wisconsin: University of Wisconsin Press, 1992.

BRANTS, K. Who's afraid of infotainment? European Journal of Communication, vol. 13, no.3, 1998: 315-335.

CASTELLS, Manuel. A sociedade em rede. São Paulo: Paz e Terra,1999.

CORREIA JÚNIOR, M. Um desafio permanente: produtos devem agregar interesse. Jornal ANJ,
Brasília, maio de 2001:.3.

DEFLEUR, M. L.; BALL-ROKEACH, S. Teorias da comunicação de massa. Rio de Janeiro: Jorge Zahar, 1993.

DE MASI, Domenico. A economia do ócio: Bertrand Russel \& Paul Lagargue. Rio de Janeiro: Sextante, 2001.

DEUZE, M. Education 'new' journalists: challenges to the curriculum. Journalism \& Mass Communication Educator, v.56, n.01, 2001: 04-17.

DUMAZÉDIER, J. Lazer e cultura popular. 3a ed. São Paulo: Perspectiva, 2001

GABLER, N. Vida o filme: como o entretenimento conquistou a realidade. São Paulo: Companhia das Letras, 1999.

KOVACH, B.; ROSENSTIEL, T. The elements of journalism: what newspeople should know and the public should expect. New York: Crown Publishers, 2001.

LIMA, L. O. O brasileiro em números. Época, no.367, p.82-88, 30 de maio de 2005.

MAFFESOLI, M. À sombra de Dionísio. Rio de Janeiro: Zahar, 1989.

A comunicação sem fim (teoria pós-moderna da comunicação). Revista FAMECOS, Porto Alegre, no. 20, 2003, p.15-27.

MASUDA, Y. A sociedade da informação como sociedade pós-indústrial. Rio de Janeiro, Zahar, 2002.

TARRUELLA, R. M.; GIL, J.Garcia-Lavernia. Noticias frente a hechos: entender la realidad después de leer los periódicos. Barcelona: CIMS, 1997.

TOFFLER, A. A terceira onda. Rio de Janeiro: Zahar, 1980.

\section{Referências webgráficas}

BLAKLEY, J. Entertainment goes global: mass culture in a transforming world. Lear Centrer. Disponivel em: http://www.entertainment.usc. edu/. Acesso em: 20 de ago. 2006. 
CHANGING definitions of news. Committee Concerned of Journalis. Washington. Disponível em: http://www.journalism.org. Acesso em 03 mar. 2006.

NEWS as entertainment/entertainment as news: if people are interested, are the news media doing anything wrong? Committee of Concerned Journalist. Disponível em: www. journalism.org./uscreport.html. Acesso em: 22 abril de 2006.

Recebido em 3 de março de 2008 Aprovado em 28 de abril de 2008 